Vicenta Giménez Molla \& Amaia Alejos Martín A Traumatic Event

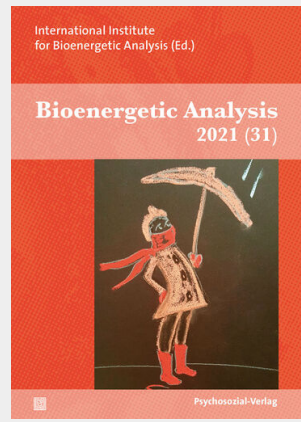

Bioenergetic Analysis

31. Volume, No. 1, 2021, Page 111-129

Psychosozial-Verlag

DOI: 10.30820/0743-4804-2021-31-111 
Reviewers for this issue:

Léia Cardenuto, Garry Cockburn, Maê Nascimento and M. Rosaria Filoni

Translators of abstracts for this issue:

Angelina Samartova (Russian), Claudia Ucros (French), Karin de Marval (Spanish), Maê Nascimento (Portuguese), Maria Rosaria Filoni (Italian), Thomas Heinrich (German) and Rebecca Jianpu Liu (Chinese)

Submissions for consideration for the next volume of Bioenergetic Analysis must be sent to Maê Nascimento (maenascimento@terra.com.br) between June $1^{\text {st }}$ and September $1^{\text {st }}$, 2021.

Bibliographic information of Die Deutsche Nationalbibliothek (The German Library) The Deutsche Nationalbibliothek lists this publication in the Deutsche Nationalbibliografie; detailed bibliographic data are available at http://dnb.d-nb.de.

2021 Psychosozial-Verlag, Gießen, Germany

info@psychosozial-verlag.de

www.psychosozial-verlag.de

\section{(C) $(1) \Theta$}

This work is licensed under the Creative Commons Attribution-NonCommercialNoDerivatives 4.0 International License (CC BY-NC-ND 4.0). This license allows private use and unmodified distribution, but prohibits editing and commercial use (further information can be found at: https://creativecommons.org/licenses/by-nc-nd/4.0/). The terms of the Creative Commons licence only apply to the original material. The reuse of material from other sources (marked with a reference) such as charts, illustrations, photos and text extracts may require further permission for use from the respective copyrights holder.

Cover image: Vincentia Schroeter, Umbrella girl (c) Vincentia Schroeter Cover design \& layout based on drafts by Hanspeter Ludwig, Wetzlar Typesetting: metiTec-Software, me-ti GmbH, Berlin, www.me-ti.de

https://doi.org/10.30820/0743-4804-2021-31

ISBN (PDF-E-Book) 978-3-8379-7809-4

ISBN (Print) 978-3-8379-8363-0

ISSN (Online) 2747-8882 • ISSN (Print) 0743-4804 


\title{
A Traumatic Event
}

\section{Bioenergetic Therapy Applied in a Company Environment}

\author{
Vicenta Giménez Molla \& Amaia Alejos Martín
}

Bioenergetic Analysis • The Clinical Journal of the IIBA, 2021 (31), 111-129

https://doi.org/10.30820/0743-4804-2021-31-111

CC BY-NC-ND 4.0

www.bioenergetic-analysis.com

\section{Abstracts}

The article describes a work of Bioenergetic Analysis performed in the business sector. The therapists provided group therapy in a company context in a situation of serious grief (an employee had been killed in an occupational accident while several of his colleagues were present). Good results were achieved. Initially, the client requested individual psychological therapy for the thirty colleagues of the deceased man. This request was redefined to cover two approaches: immediate individual therapy (for those employees most affected) and group therapy. This paper describes the group therapy performed in the company environment. The paper also discusses some of the techniques used; the theoretical basis (Lowen's Bioenergetic Analysis); incorporation of neurological advances on trauma (Porges' Polyvagal Theory), trauma treatment (Berceli, Levine, Ogden, Rothschild and Van der Kolk); and the concepts that might be most helpful for anyone replicating this work in similar contexts.

Keywords: trauma, grief, therapy, company, bioenergetic analysis.

Um evento traumático. Terapia bioenergética aplicada em ambiente empresarial (Portuguese)

$\mathrm{O}$ artigo descreve uma intervenção bioenergética num contexto laboral. Os terapeutas organizaram um grupo terapêutico na empresa que havia passado por um luto grave (um trabalhador ficou aprisonado num acidente laboral presenciado por vários colegas). Resultados muito bons foram atingidos. Num primeiro momento o cliente havia pedido psicoterapia individual para os trinta colegas da pessoa que faleceu. Esta demanda foi redefinida em duas modalidades: terapia individual (para os mais atingidos) e terapia de grupo. Este artigo descreve a terapia de grupo realizada no ambiente de trabalho. Descreve algumas técnicas utilizadas; a base teórica (a análise bioenergética de Lowen); a integração da consciencuia avançada do trauma (a teoria polivagal de Porges); o tratamento do trauma (Berceli, Levine, Ogden, Rothschild, Van der Kolk); e os conceitos que poderão ser de utilidade na expectativa de uma possivel replicação desse trabalho em contextos similares. 


\section{Un evento traumático. Terapia bioenergética aplicada a un medio corporativo (Spanish)}

El artículo describe una intervención en Análisis Bioenergético llevado a cabo en un ambiente de trabajo. Los terapeutas organizaron terapia de grupo en un contexto laboral para una situación grave de duelo (un empleado había muerto en un accidente de trabajo con varios de sus colegas presentes). Se obtuvieron buenos resultados. Inicialmente, el cliente solicitó psicoterapia individual para los treinta colegas del hombre muerto. Esta demanda fue redefinida buscando abarcar dos modalidades: terapia individual inmediata (para aquellos empleados más afectados) y terapia de grupo. Este artículo describe la terapia de grupo desarrollada en el medio corporativo. También discute algunas de las técnicas usadas: la teoría de base (Análisis Bioenergético de Lowen), la integración de los avances neurológicos sobre trauma (Teoría Polivagal de Porges), el tratamiento del trauma (Berceli, Levine, Ogden, Rothschild y Van der Kolk); y conceptos que pueden ser de ayuda para quien desee reproducir este trabajo en contextos similares.

\section{Un evento traumatico. La terapia bioenergetica in ambiente lavorativo (Italian)}

L'articolo descrive un intervento bioenergetico realizzato in un contesto lavorativo. I terapeuti hanno organizzato un gruppo di terapia in una società in seguito a un lutto grave (un dipendente era rimasto ucciso in un incidente lavorativo alla presenza di vari colleghi). Sono stati ottenuti buoni risultati. Dapprincipio il cliente aveva fatto richiesta di terapie individuali per i trenta colleghi della persona deceduta. Questa richiesta è stata ridefinita in due modalità: terapie individuali immediate (per i dipendenti più sofferenti) e terapia di gruppo. Questo articolo descrive la terapia di gruppo realizzata nell'ambiente di lavoro. Espone anche alcune tecniche utilizzate: la base teorica (l'analisi bioenergetica di Lowen): l'integrazione delle conoscenze avanzate sul trauma (la teoria polivagale di Porges); il trattamento del trauma (Berceli, Levine, Ogden, Rothschild, Van der Kolk); e concetti che possono essere di aiuto a chi volesse replicare in contesti simili questo lavoro.

\section{Un événement traumatique. Thérapie en Analyse Bioénergétique appliquée en entreprise (French)}

Larticle présente un travail d'Analyse Bioénergétique effectué dans le secteur des entreprises. Les thérapeutes ont dispensé une thérapie de groupe dans un contexte d'entreprise en situation de deuil grave (un employé avait été tué dans un accident du travail alors que plusieurs de ses collègues étaient présents). De bons résultats ont été obtenus. Au départ, lemployeur a demandé une thérapie psychologique individuelle pour les trente collègues de l'homme décédé. Cette demande a été redéfinie pour offrir deux approches : une thérapie individuelle immédiate (pour les employés les plus touchés) et une thérapie de groupe. Le présent article décrit la thérapie de groupe effectuée dans le contexte de l'entreprise. Il examine également certaines des techniques utilisées, les bases théoriques (Analyse Bioénergétique de Lowen), la prise en compte des avancées neurologiques sur les traumatismes (Théorie Polyvagale de Porges), le traitement des traumatismes (Berceli, Levine, Ogden, Rothschild et Van der Kolk) et les concepts qui pourraient être les plus utiles pour quiconque reproduit ce travail dans des contextes similaires. 
Ein traumatisches Ereignis. Bioenergetische Therapie angewandt in einem Firmenumfeld (German)

Der Artikel beschreibt ein Projekt der Bioenergetischen Analyse im Unternehmensbereich. Die Therapeutinnen boten Gruppentherapie in einem Firmenkontext bzgl. einer Situation tiefer Trauer an: Ein Mitarbeiter war bei einem Arbeitsunfall getötet worden, während mehrere seiner Kollegen anwesend waren. Es wurden gute Ergebnisse erzielt. Ursprünglich hatte der Auftraggeber um eine psychologische Einzeltherapie für die dreißig Kollegen des Verstorbenen gebeten. Dieser Wunsch wurde umdefiniert und umfasste zwei Ansätze: sofortige Einzeltherapie für die am meisten betroffenen Mitarbeitenden und Gruppentherapie. Dieser Beitrag beschreibt die Gruppentherapie, die im betrieblichen Umfeld durchgeführt wurde. Außerdem werden einige der angewandten Techniken, die theoretische Grundlage (Lowens Bioenergetische Analyse), die Einbeziehung neurologischer Erkenntnisse zum Thema Trauma (Porges' Polyvagal-Theorie), die Traumabehandlung (Berceli, Levine, Ogden, Rothschild und Van der Kolk) und die Konzepte besprochen, die für jede Person, die diese Arbeit in ähnlichen Kontexten wiederholt, am hilfreichsten sein könnten.

Травмирующее событие. биоэнергетическая терапия в корпоративной среде (Висента Гименос Молла и Амайя Алехос Мартин) (Russian)

В статье описана биоэнергетическая работа в рабочем коллективе. Терапевты проводили групповую терапию в компании, где царила сильная скорбь (в результате несчастного случая на производстве погиб сотрудник, при этом присутствовало несколько его коллег). Были достигнуты хорошие результаты. Первоначально клиент просил об индивидуальной психотерапии для 30 коллег погибшего. В итоге запрос был переформатирован, и работа велась по двум направлениям: неотложной индивидуальной терапии (для наиболее пострадавших сотрудников) и групповой терапии. В статье описана групповая терапия, проведенная в корпоративной среде. В ней также рассмотрены некоторые из использовавшихся методик; теоретическая база (биоэнергетический анализ Лоуэна); включение нейрологических разработки в области травмы (поливагальная теория Порджеса), лечение травмы (Берсели, Левин, Огден, Ротшильд и Ван дер Колк); а также концепции, которые могут оказаться полезны для любого, кому придётся работать в подобных обстоятельствах.

创伤事件。身体动力分析治疗在企业中的应用 (Chinese)

这篇文章报告了躯体动力分析在一企业部门中的应用。治疗师在企业环境中给一个正在经历严重 丧失的部门提供团体治疗 (一位雇员在职业事故中被杀，当时有几位雇员在场)。此治疗取得了 良好的效果。起初，客户要求对逝者的 30 位同事进行个体治疗，这个请求被分为两个方式进行: 对最受影响的员工立刻进行的个体治疗和团体治疗。本文描述了在公司环境中进行的团体治疗和 治疗中运用的一些技术。治疗理论依据 (勒温的躯体动力分析)；神经生物在创伤中的应用（多 迷走神经理论）；创伤治疗（Berceli, Levine, Ogden, Rothschild and Van der Kolk）；和一些可能 帮助到有意在相似情景运用治疗的一些概念。 


\section{Part One: \\ Description and Assessment of the Therapeutic Process}

\section{Introduction}

The client was the manager of a furniture-manufacturing firm that advertises a "great love of nature - we are wood". The company distributes its locally produced goods in six European countries. It claims to be a pioneer in social issues in its industry. Since it was founded, the company has prioritized gender equality, striking a balance between employee-wellbeing and the viability of the company's projects and respecting work/life balance.

In the first telephone contact, the client identified herself and said they had "suffered a misfortune". One of their employees had died in a workplace accident. She requested individual psychological therapy for the employee's thirty colleagues. Given the impossibility of meeting this request, the gravity of the circumstances and the need to act quickly (further aggravated by the fact that the summer holiday period was drawing near) the response was redefined, and two paths of action decided upon: individual and group therapy. This paper discusses details of the group therapy. It should be noted that throughout the process, parallel individual therapy was conducted with some of the employees.

\section{Phase I: Therapeutic Emergency}

\section{Individual Therapy}

Individual therapy began during the week following the accident. The initial users were the two colleagues who had been first to attend the victim of the accident and who had tried unsuccessfully to revive him. The client described these employees as being "in a state of shock". They were initially attended by one of the therapists at her clinic during the three weeks before the company's annual summer holiday period began, in weekly 90 -minute sessions.

\section{Group Therapy}

Group therapy began two weeks after the accident and was held once a week until the holiday period (two weeks). The thirty employees from that department are mostly divided into two shifts, working alternately mornings and afternoons/evenings. Therapy took place outside working hours in a room provided on the firm's premises (with sofas, carpets, blankets and cushions). Each session was 120 minutes long. In keeping with the company's policy on work/life balance, the therapists were asked to provide therapy on site. They were available 
to give the sessions on one day (Monday) every week. The morning group session was attended by twelve users and the afternoon session by thirteen. The five users who did not attend the group sessions included one of the employees who was attending individual sessions and whose working hours clashed with the group sessions. Attendance was voluntary, although the company recommended that all staff should attend. For most, this was their first contact with the world of psychology. The intervention on the first day consisted of two stages: initial contact (with therapists and users introducing themselves) and body work.

The first group consisted of twelve users (seven women and five men) who were strongly affected by their experience of the accident. They reported fear, anger, disbelief and knotting in the chest and stomach. They also had invasive images, difficulty in sleeping, eating and concentrating. Several reported that they had been unable to move when the incident occurred and wondered whether they could have done more to save the victim. (When the health services arrived, they confirmed that he had died "instantly" and that given his injuries, it would have been impossible to resuscitate him). Some users described how they had looked at "the body" several times because they couldn't believe what had happened. They described the deceased as "a very cheerful person, the life and soul of the group".

The second group consisted of thirteen users (eight men and five women). Only two members of this group were present at the time of the accident. One of these two later sectioned part of her fingertip in an occupational accident after returning to work (the plant closed for several days after the accident). She is also a friend of the deceased's family (several other users also had a personal friendship, either with the deceased, or with his family). The other person who was present at the time of the accident was a young man who had joined the company recently and was only planning to stay a couple of months. He was one of the first to tend to the victim, whom he did not know. He reported having images at night that he was unable to get out of his head. He would like to forget what he saw. He was glad he did not know the deceased. If he had, he would not have been able to do as much as he did. Most reported feelings of disbelief and expecting the deceased man to walk in the door at any moment.

The intensity of the experiences of fear, anger/rage, grief and trauma varied greatly among different groups and users. In general terms, we encountered users with shallow breathing, energy in the upper part of the body and poor grounding with lifeless legs. In relational terms, each individual was isolated in his or her own world of sorrow.

In both groups, following the initial introductions, which were conducted in a square, with users sitting on sofas and armchairs, the group dynamic involved getting the body moving and shaking off its immobility. Therapists and users stood in a circle. Users were instructed on good grounding, to enable them to feel their bodies and become aware of their feelings and needs at that precise mo- 
ment in time, and also to feel their breathing. Each user verbalized the sensation they were most aware of, or which was making them most uncomfortable. This enabled body work that was both individual and at the same time, group-focused, with the rest of the group accompanying the individual user. One user reported trembling throughout his body, like a sort of inner electricity. The therapist recommended voluntary movements that would exaggerate and exteriorize that feeling, "like a gazelle escaping from a lion". The rest of the group accompanied the movement (other users reported feeling the same). This produced laughter among the group when they looked at one another. One woman, who was incapable of putting her feelings into words and had to choke back tears during the first part of the session, pointed at her throat. Using affirmative and negative gestures, the therapist concluded that she could not speak because of the emotion and felt blocked. The therapists recommended that she move her body by jumping up and down "like a Masai". The group accompanied her. As she began to breathe more deeply, she was able to make an "aaaabhbhb" sound and the therapists suggested that she should hum a song while completing the jumping. The group recognised the song ("Xuxa Ilarie") and joined in, singing and performing the associated dance, which involves jumping. This again sparked laughter. After completing this exercise, the user was able to put words to her feelings and asked for a group hug. The session ended on this very emotional moment.

\section{Assessment}

Sixty percent of the employees attended the second day of group sessions, mostly those who were present at the time of the accident. An assessment of symptoms was carried out, using the criteria for Acute Stress Disorder ${ }^{1}$ (ASD), (DSM-5, 2014). The occurrence of intrusion, dissociative, avoidance and arousal symptoms differed considerably between users who did not witness the accident (average 1.3 symptoms) and those who did (average 7.28 symptoms). There was also a clinically significant intensity of distress, and deterioration in social and occupational aspects and other important areas of their lives, to very different extents.

Of the users who were present at the time of the accident, 100\% reported arousal symptoms (hypervigilance and exaggerated startle response), 70\% intrusion symptoms (recurring, involuntary distressing memories of the accident) and $70 \%$ dissociative symptoms (altered sense of the reality of their surroundings, such as feeling stunned or time going slow). $60 \%$ suffered intense or prolonged psychological distress or major physiological reactions to internal or external cues symbolizing or resembling the accident (intrusion symptoms), together with irritability (arousal symptoms).

1 The symptoms lasted from the third day traumatic event after the accident to one month later. 
Of the users assessed who were not present at the accident, only $50 \%$ reported some symptom, the most frequent being arousal symptoms, especially hypervigilance and exaggerated startle response.

Following the initial ASD assessment, three users were identified who met all the diagnostic requirements while a further three were in serious risk of meeting them.

\section{Body Work in Group Sessions}

The body work conducted on this second day of group sessions was based on Bioenergetic Analysis (BA) and David Berceli's trauma release work (2012). After briefly moving their entire body, the users were placed in pairs. The work includes special exercises for releasing trauma and manual procedures such as facial and occipital massage to relax tight face, neck and shoulder muscles. All users were told to breathe through their mouths and concentrate on the feelings from their bodies. Described below are the steps involved in the facial and cranial massage, which users performed in pairs with short instructions from the therapist.

One user lies with their feet well supported on the ground and the other positions themselves at his/her head:

$>$ Step 1: The massage begins in the nasal region, from the apex of the nose, over the ala (wings) of the nose, without pressing them, and rising towards the root of the nose, with a slight pressure.

> Step 2: The massage continues along the arch of the eyebrow, from the nose towards the temporal area.

$>$ Step 3: The thumbs are placed in the glabella, encompassing the forehead, and spread along the superciliary arch, from the centre towards the periphery.

$>$ Step 4: The thumbs are placed on the orbitary portion of the orbicularis oculi muscle, pulling upwards from the nose towards the ear (cheekbones).

$>$ Step 5: The pulling motion is continued with the tip of the other four fingers, under the earlobe as far as the occipital base.

$>$ Step 6: The tips of the fingers are placed approximately around the fifth cervical vertebra and the upward pulling motion is continued along the trapezius muscle again as far as the base of the occipital region, pressing and performing a light movement of stretching and rotation of the head in both directions, slowly. The reclining user has to make sure to leave the weight of the head in the hands of his/her partner. The stretching motion is kept up for approximately 1 minute.

This massage is a variation on that proposed by Lowen and Lowen (2012) in their neck and head exercises. The shoulder is then pressed in the opposite direction to the head, to help stretch that entire area. 
After the session, all users were seen to have a relaxed expression, a brighter look (some users reported seeing more clearly) and the "pleasant" surprise of feeling their bodies vibrate. They all reported greater wellbeing, relaxation and were pleased with the work performed.

In this first stage, the BA work was oriented towards helping users become aware of their body and emotions and expressing that awareness. One basic objective in this first phase was to establish and reinforce a bond of trust amongst group members, by means of exercises encouraging contact and relationship (for example, encouraging visual contact between them). The users began their summer holidays, and this stage of the work came to an end. The therapists had different holiday dates and remained available for individual therapy sessions for a further two weeks.

After the holidays, the client decided to continue with the group sessions. The client informed the therapists that there had been a fatal workplace accident at another firm, and this had revived symptoms among their employees. She said the latest victim was known to most of them. A second stage of group sessions was scheduled. The frequency and timetable for the sessions was agreed on by the users and the client and confirmed by the therapists: four fortnightly sessions; one 120minute morning session and one 60-minute afternoon session. The work continued with two groups. The reason for the shorter afternoon hours was the need to respect the employees' work/life balance ("They have to pick up the kids from school"). An extra fifth session was added before the Christmas holiday period.

\section{Phase II: Grounding, Treatment of Traumatic Memories and Grief}

During this second phase an average of twelve employees were counselled, between the group and individual sessions, representing $42 \%$ of employees. $72 \%$ the group who were present at the time of the accident (ten employees) attended, as compared to $14 \%$ of those who did not (two employees). $75 \%$ of attendees were women and $25 \%$ men. $100 \%$ of the women who witnessed the accident attended the group and/or individual sessions during Phases I and II.

At the first group meeting after the holidays, users and therapists re-established contact. This relapse came after the accident at the other firm and for all of them, following their return to work. Weeping was very commonplace in the sessions. Several users remarked, "I don't understand what's happening to me; I should be better by now". The therapists explained about the body's main defensive strategies, and about normalizing and making sense of the symptoms and reactions. The fight/flight/freeze, as well as auditory hypersensitivity, hypervigilance and development and evolution of Post-Traumatic Stress Disorder ${ }^{2}$ (PTSD), based

Symptoms present after the traumatic event, from one month. 
on DSM-5 criteria were also explained. Of the nine participants, three fulfilled the criteria for PTSD and another two were at risk of meeting them. Each participant got in touch with their feelings and the therapists performed trauma release body work, as per Berceli (2012). All participants reported that they were calmer on leaving than when they arrived.

The Phase II sessions began with an exercise to encourage awareness of the body through the participants' breathing and needs, following the movements of the body and observing the changes that followed. Users were seen to have difficulty in establishing good grounding, with the energy clearly having shifted upwards, in a group defence mechanism. It was therefore particularly important to promote grounding and perform leg work, so that they can hold themselves up and tolerate the situation experienced in all its intensity. For this purpose different exercises were emphasized in different sessions, for example:

$>$ In a standing position, feeling the weight in both legs, then feeling it only in one leg, and then in the other

$>$ Lying face up, legs flexed and raised, lifting the ankles towards the ceiling

$>$ Special emphasis was placed on performing the forward bend.

Each user had different needs and a different pace through the sessions, and therefore space was given to working with each one, using more sensorial work, as proposed by various theorists such as Levine (2013, 2016, 2018), Ogden, Minton and Pain (2009), Rothschild (2015), and Van der Kolk (2015) and evolving towards a work of greater bioenergetic intensity, as proposed by Klopstech (2005).

Particular importance was given to the creation of "safety islands or anchors" (Levine and Rothschild), the capacity to sway and regulate oneself, remaining within the window of tolerance. These spaces are internal and private shelters where the user knows that they can go when necessary if the session becomes particularly intense. Having two therapists meant that more tailored attention could be given to individual and group needs; sub-groups were created in some sessions, with one therapist guiding the session and the other regulating anyone who so required.

During this phase Autumn set in, and the heating in the room proved insufficient. The therapists improvised by bringing small stoves and heating the room before the users arrived, thus emphasizing the warmth of the contact to be offered and the importance of a genuine caring relationship to facilitate the process. They also brought towels and exercise balls of different sizes. The session with the balls enabled variation in the body work and allowed the participants to engage in play. In general, all users had lifeless legs, and the therapists therefore worked on good grounding and getting in touch with feelings of rage and annoyance (e.g., by twisting towels). Expressing feelings of anger or annoyance was considered necessary for the grief-healing process, always taking into account each person's individual pace of grief. 


\section{Assessment}

PTSD criteria were again assessed in the last session of this phase, and a considerable reduction in symptoms was observed compared to the start of the phase. Users displayed an average of 2.5 symptoms (arousal symptoms such as hypervigilance and exaggerated startle response). There was also a considerable reduction in intrusion symptoms such as involuntary memories of the accident, dissociative symptoms such as fragmented memories and evasion symptoms such as avoiding memories of the accident.

On completion of Phase II, it was proposed to the client and users that a third phase should begin after Christmas, to continue to develop the grief process and avoid complicated grief. In their proposal to the client, the therapists suggested that in Phase III there should be a single group in the morning. The company collaborated, making it easy for employees to swap shifts to attend the sessions. Initially, all agreed, but several users had difficulty in attending.

\section{Phase III: Grief Integration and Elaboration}

The seven participants (five women and two men) in Phase III came from the group that was present at the time of the accident. The client and users agreed that four 120-minute sessions should be held once a month, and this was confirmed by the therapists.

In Phase I, a good bond had been established amongst the group members and between them and the therapists. In Phase II, grounding had been reinforced. The therapists' main target in Phase III was the expression and integration of the emotions. Although the users found it difficult to express their sorrow, their grief became more evident. However, they did not feel they had a right to feel and express rage.

The following bioenergetic exercises were used, among others, to help users express their rage:

$>$ In supine position, with their feet supported on the carpet, they slowly twist a towel in front of their eyes.

$>$ On all fours, they move their back in time with their breathing (arching the back up and down). This exercise is first performed individually, and then in facing pairs, emitting noises and grunts (like two cats confronting each other).

$>$ They face each other in pairs and kick out.

After these exercises any sensations and emotions that had arisen were listened to and accepted. The progression in each session was as follows:
a) making contact;
b) working the body; 
c) working on themes that arise; and

d) ending the session.

During Phase III, the therapists indicated one aspect of each user's work. They worked with each one on anything that might have come up, but within the group. Special importance was given to placing a positive value on aggressive force, since the right to get angry and feel their own rage appeared be taboo for them. The therapists worked on enabling them to be well grounded, fostering feelings of security, confidence and empowerment. The specific character structure and attachment style of each user was taken into consideration.

\section{Assessment}

In the last session, the progress made by each user was validated and the therapists spoke of their pride in them and the bravery they had shown in confronting their pain, suffering and traumatic experiences. PTSD-compatible symptoms were again measured. The results were similar to the previous assessment, but users reported that the symptoms were less intense. The therapists discussed the importance of performing some grief ritual on or around the anniversary of the death, which was still some months away. Several users said they were afraid of the anniversary, which coincided with one participant's birthday. They thanked the therapists for their work and expressed an interest in continuing with the group sessions. The client also thanked them for their work but considered that it was sufficient for the moment. At this point the therapeutic intervention came to an end. Table 1 provides an overview of the Phases and Timeline of the work completed.

\begin{tabular}{|c|c|c|c|c|c|c|}
\hline Timeline & $\begin{array}{l}\text { Frequency } \\
\text { Sessions }\end{array}$ & $\begin{array}{l}\text { No. Days } \\
\text { Sessions }\end{array}$ & $\begin{array}{l}\text { Session } \\
\text { Time }\end{array}$ & $\begin{array}{l}\text { Session } \\
\text { Duration }\end{array}$ & $\begin{array}{c}\text { Total } \\
\text { Group } \\
\text { Sessions }\end{array}$ & $\begin{array}{l}\text { Total Group } \\
\text { Work Hours }\end{array}$ \\
\hline $\begin{array}{l}\text { Phase 1: } \\
\text { Therapeutic } \\
\text { emergency }\end{array}$ & Weekly & 2 & $\begin{array}{l}\text { Mornings } \\
\text { and } \\
\text { Afternoons }\end{array}$ & $\begin{array}{l}\text { Morning }-2 \text { hrs } \\
\text { Afternoon }-2 \text { hrs }\end{array}$ & 4 & 8 hours \\
\hline $\begin{array}{l}\text { Phase 2: } \\
\text { Treatment of } \\
\text { traumatic } \\
\text { memories }\end{array}$ & Fortnightly & 5 & $\begin{array}{l}\text { Mornings } \\
\text { and } \\
\text { Afternoons }\end{array}$ & $\begin{array}{l}\text { Morning }-2 \mathrm{hrs} \\
\text { Afternoon }-1 \mathrm{hr}\end{array}$ & 10 & 15 hours \\
\hline $\begin{array}{l}\text { Phase 3: } \\
\text { Grief integration } \\
\text { and elaboration. }\end{array}$ & Monthly & 4 & Mornings & Morning $-2 \mathrm{hrs}$ & 4 & 8 hours \\
\hline Total & & 11 & & & 18 & 31 hours \\
\hline
\end{tabular}

Table 1: Phases and Timeline of the work carried out 


\section{Anniversary Ritual Celebration}

The therapists subsequently learned of the grief ritual and the employees' experience of the date of the anniversary. On their initiative, a magnolia tree was planted in the environs of the company some days before the anniversary. This meant that on the actual date of the anniversary, they were able to celebrate their workmate's birthday. The therapists were again moved by the bravery and human warmth of these people.

\section{Part Two: \\ Demonstration of the Innovative Nature of the Clinical Experience}

Bioenergetic clinical work was performed in a company context, a situation which the therapists believe to be innovative. They are unaware of any similar work in this country. They know of individual therapy in a clinic, but not of group work at a company's premises. The therapists were able to react quickly (the individual sessions begin the week following the accident), adapt to the medium (leaving the security of the private clinic and taking the sessions to a room provided for them by the firm), and adapt to dealing with the company as the client. They showed improvisation and creativity (bringing stoves, exercise balls and towels), allowing themselves to be "infused" by the moment (to feel) and to be spontaneous in their reactions. The therapists have taken the work of BA out of the private clinic, bringing it to the business area, and have also integrated trauma therapy.

After the initial call from the client, the therapists asked colleagues for references that they might use in their work but were unable to find any. Among others, they consulted the local director of their BA training (the therapists were in their final year) and a fellow student, a psychologist, who worked in the executive coaching area. Given the gravity of the circumstances, the therapists decided to carry out this intervention despite the absence of previous references. For Phase I, they took advice from their trainer and fellow student. For Phases II and III, they took advice from a fellow CBT specializing in trauma, who watched videos of the sessions with them (the client and users gave their consent to the making of the recordings).

One of the greatest difficulties facing the therapists was to establish a therapeutic framework of clinical attention in the company. In Phase I, it was difficult to decide on the fees for the group sessions, travel, coordination with the company, etc. and to quantify the work inside and outside the group sessions, as they had no references to similar work. Management of the information flow to the company and user confidentiality constituted a delicate variable which had to be redefined in each phase. The therapists provided greater information to the 
company in Phase I, as part of a service of attention to and care of employees and harm prevention, though without acting as an occupational risk prevention service. Any information provided on the group's progress was general in nature and respected user confidentiality at all times. The framework of the relationship with the company was considered an important variable to be taken into account throughout the work; although the intervention was directed at the employees, the relationship with the company could have a specific influence on the clinical intervention. Throughout the process, the therapists were conscious of the need to establish clear limits in their relationship with the company. The therapists are not service providers and do not work within the framework of either organizational or occupational psychology or coaching, nor do they employ motivational group techniques and nor are they the client's suppliers. Throughout the process they have constantly had to establish limits. To facilitate this, all communication with the client was performed by the therapist in charge of the project.

\section{Part Three: \\ Demonstration of Applicability and Validity for Other Professionals}

During 2017, 618 people died in their workplace in Spain, and 652 during 2018 (statistics from the Ministry of Labor and press reports). One of these was employed at our client's company and was a workmate of our users.

According to Lowen, neither possessions nor salaries foster joy in living. Today's society does not promote the life of the body nor the search for health, instead stressing money and power. Yet the true purpose of life is pleasure and joy. In primitive societies, Lowen tells us, when the beloved object is important, its loss is not accepted without a show of anger and protest. If no rage is felt at a loss, true sorrow cannot be experienced and there can be no proper grieving. It is necessary to be conscious of that suppressed anger and to express it. As Lowen puts it, it is like defusing a bomb that one is carrying (Lowen, 1980, 2004, 2005, 2013, 2014). Beneath the anger, lies pain, but we live in a society that fears anger over loss, and it is therefore necessary to permit the expression of annoyance: did it have to happen? did it have to happen in this way? could it have been avoided? (Kübler-Ross \& Kessler, 2006). The users either did not feel rage - a fundamental emotion in the grief process - or did perceive it but did not feel entitled to express it. These defence mechanisms and forms of resistance are common. Once a solid safe base had been established, in Phase III they worked on getting in touch with their feeling of rage and expressing it freely, feeling themselves to be released from that charge.

Sometimes they got annoyed with colleagues whose pattern of grief was different to theirs. A photo of the dead man was hung in the company, but not everyone took this well. For some, seeing it increased their pain; others avoided 
looking at it or walking past the place where their colleague had been killed, considering that particular floor area to be "sacrosanct". Something similar happened at the company's Christmas dinner. This was the first time that the two departments - those who had been present at the accident and those who had not - all came together, and it aroused contradictory feelings which were worked on in the sessions. Van der Kolk (2015) reports that after trauma, the world is clearly divided between knowers and non-knowers. Knowers cannot take those who have not shared the traumatic event into their confidence, because they cannot understand it. Sadly, this often includes family, friends and workmates.

This paper describes the various sequences of the different exercises. Bioenergetic exercises are not designed to make the person stronger, but to make them feel more and more vibrantly alive. The purpose of bioenergetics, says Lowen, is to be capable of seeing and understanding corporal expressions. Emotions are the life of the body, just as thoughts are the life of the mind. One of the main purposes of bioenergetic exercises is to help feel the body and come into contact with it. This is necessary because many people live in their heads, with very little awareness of what is happening below their necks. They are unaware whether they are holding their breath, or whether their breathing is shallow or deep. Most people do not feel their legs and feet. They know they are there but use them merely as mechanical supports (Lowen \& Lowen, 2012). These ideas were present throughout the process, but especially in Phase II, when the therapists encouraged grounding and emphatically sought to give the group members a greater connection with the ground.

The components of BA are breathing, weeping, footwork and ever deeper vibrations, so that they can flow freely up through the body with the help of breathing (Lowen, 2004). The importance of bottom-up work has been confirmed by advances in neuroscience and by trauma theorists (Berceli, 2012; Le Doux, 1998, cited in Payás, 2010; Levine, 2013, 2016, 2018; Ogden, Minton \& Pain, 2009; Porges, 2016, 2018; Rothschild, 2015; Van der Kolk, 2015).

Polyvagal Theory challenges us to think in terms of two-way and hierarchical neural feedback circuits involving communication between the peripheral organs and the different brain structures. It also questions the therapist's interpretation of certain atypical behaviour and physiological reactions and suggests that they may have an adaptative function. With these organizing principles, Polyvagal Theory is very useful for understanding the characteristics that facilitate and optimize human social behaviour and health (Porges, 2016; Schroeter, 2016). Van der Kolk (2015) argues that Polyvagal Theory allows therapists to be more aware of the combination of top-down approaches (to activate social interaction) and bottom-up methods (to calm physical tensions in the body). Everything is based on interpersonal rhythms, visceral awareness and vocal and facial communication, which help people to escape from states of fight/flight, to reorganize their perception of danger and to increase their capacity to manage relations. 
Schroeter and Thomson (2011) tell us that for the BA therapist it is useful to know and understand these contributions, which allow us to understand the nervous system's dynamic in relation to trauma. However, these systems do not usually take into consideration the complexity of character structure and the way in which it interacts with trauma. BA provides useful techniques that function with acute trauma, whilst still taking into account our understanding of the complex a dynamics of character structure. It is important to respect each user's rhythm in processing this stage of his/her own path. Someone suffering from PTSD may bring their usual characterological coping skills into action. Therefore, a combination of working with a trauma model (honoring the nervous system by using work to activate the frozen impulse to fight and flee) and using Bioenergetic techniques that work to regulate expression (either containment, or expressive) would be appropriate. According to these authors, the role of the therapist consists of creating security, of observing and following the user, with a calm voice, orienting them in the here-and-now and inviting them to follow their own pace.

Berceli (2012) argues that the effects of workplace trauma can be so severe that it is economically imperative on companies to treat this condition. Once the trauma contaminates the corporate area, neither the most skillful strategies, the most perceptive crisis management techniques nor the sharpest business acumen can effectively deal with it. Mistrust is a barrier that is so difficult to overcome that many organisations engage a series of mental exercises to restore confidence among their employees. However, trauma-damaged individuals have a neurological impediment to trust, tinted by their life-or-death perspective. Berceli states that if a firm tells its staff to seek psychological help elsewhere, without taking charge of the process, it is adopting a detached approach. The implied message is "This is your problem, not ours. It doesn't concern us". This can create a feeling of defenselessness among employees. In our intervention the different exercises proposed by Berceli were present in the three phases. Our users had suffered a strong traumatic situation and required effective techniques to recover their confidence and security.

Winnicott (1971, cited in Ogden, Minton \& Pain, 2009), says that one of the fundamental tasks of the therapist is to help patients learn to play. Stimulation of the action system responsible for play and the corresponding emotions of fun and pleasure are especially important in therapy with traumatized patients, who are often incapable of undertaking recreational behaviour. Play uses the social engagement system to indicate that the intentionality of the movements is neither dangerous nor harmful and that connecting and co-regulating with others is our biological imperative (Porges, 2018). As this author says, rocking on an exercise ball may be an alternative way of stimulating central regulation of the vagus nerve. He further argues that singing is a neuronal exercise of the social engagement system. Singing requires slow exhalations, controlling the facial and cranial muscles, to generate the modulated sounds that we recognise as vocal music. The slow exhalations calm the autonomous state, by increasing the impact of the ventral 
vagal pathways of the heart. When we sing, we exercise or entire integrated social engagement system. In Phase I, following group singing and dancing, the members felt much more closely united, and were able to look each other in the face again, make eye contact and smile. Listening to their colleagues and sharing their feelings in a regulated fashion enabled them to feel more united to the group. At other points in our intervention, play was also present (for example, throwing cushions at each other) which helped establish a bond and a social engagement.

Payás (2010) refers to grief by work colleagues as unauthorized grief; they are not recognised by society as grieving subjects who need to be listened to and supported, requiring special attention. Phrases such as "are you still feeling like that?", "think about other things, distract yourself", "crying won't do any good", "you should be over it by now", reflect that empathic failure of the surroundings, the effect of which is accumulative trauma, which can presage complicated grief.

Just as there is no general theory of grief encompassing all the many different aspects involved in adapting to the breaking of an emotional bond, neither is there any one supermodel of psychotherapy that allows the professional clinician to attend to all the different facets and dimensions of the grief process (Payás, 2010). Wanting to save a life does not mean being able to prevent a death. This was a situation faced by one of our users; she had tried to revive her colleague, but it was impossible. According to Poletti and Dobbs (2004), performing a ritual on the anniversary allows people to confirm the reality of the loss, express their emotions, share the pain with other colleagues, speak about the deceased, share their memories and, in short, process their grief. The users planted a tree together with their colleagues. The tree they chose was a magnolia, which is native to the USA (webs, 2018). In China it is considered as a symbol of love for nature and great nobility of character. Infusions of its bark have healing properties for the heart and nerves. Poletti and Dobbs say that funerary rites provide a kind of hope in a life that continues beyond physical death. Through this tree, his companions expressed the end of one stage and the beginning of another (curing), their love for their deceased colleague, for nature, for wood and their connection with the earth.

\section{Part Four: \\ Demonstration of the Experience as a Contribution to the Development of Bioenergetic Clinical Practice}

In today's society, an individual has a greater chance of suffering a traumatic situation or of witnessing one. No psychological approach should ignore this, and professionals who practise BA must make an effort to adapt their clinical practise to this situation. Early attention in trauma and grief are of vital importance in our society. In the words of Jaime Pérez (Pérez, 2006), there is no such thing as PTSD, only traumatized patients, each with their own particular universe. And just as 
there is no standard patient, neither is there one standard treatment, let alone an ideal one. We should bear in mind that around $20 \%$ of those affected go on to develop PTSD (Rothschild, 2005), with risk factors including being a woman and young, factors which coincide with $100 \%$ of the users who were present at the time of the accident (DSM-5).

It is of vital importance that therapists should be familiar with the latest advances in trauma treatment and should incorporate and adapt them into their theoretical corpus. Moreover, BA is particularly well-placed for this integration, given its extensive experience in working with the body and the ever-greater emphasis placed on body work in different trauma theories. This paper seeks to make a modest contribution towards a greater understanding of trauma treatment from a BA perspective.

Another important aspect of this case was that it brought bioenergetic practice out of the office and adapted the therapeutic work to the client's human and working environment. Operating in the actual working context endows the work with greater organizational significance. It is something that takes place, is dealt with and resolved in the company. An organisation suffers whenever its members suffer, and BA therapy can be relevant in the organizational context.

The prevailing disassociation in today's society promotes the idea of "keeping going" without allowing emotions to be experienced and expressed, especially in the working context. The establishment of a secure bond and grounding are preliminary requirements for the open and sincere expression of certain emotions such as rage, which are considered "a priori" to be dangerous. In the sessions we stressed the importance of becoming sensorially and emotionally aware and of a proper leave-taking - facilitating grief, and not denying it. We consider that this last ritual could be facilitated through the group cohesion achieved and the greater perception and awareness of the users' own sensations and needs.

This experience has shown that BA is a valid working tool in three new areas: work in a firm; work in a trauma situation; and intervention in a grief situation. For coping with both the trauma and the grief, a focus on bodily perceptions increases the individual's capacity for self-regulation. A contained, united group (an objective mainly achieved in the first phase) offers the individual a greater capacity for containment. The individual's capacity to establish greater grounding (second phase objective) increases this capacity for containment. From the initial stage of therapeutic emergency, we moved on to the second stage of grounding, and from this to the third stage, in which the expression and integration of the emotions allowed the elaboration of grief.

Bioenergetic Analysis offers knowledge on character structures and how one operates and handles oneself in life, and we consider that it may be applied to the working of a company. Companies are managed by people with their own character structures and attachment styles. Note the importance of the relationship at the three levels of the system: the company, the group performing the sessions 
and the individual. We have sought to bring the richness of BA and body work to the milieu of the company, in the conviction that it can be expressed more openly and more boldly and made available to a wider public (company, social services, health, education, etc.) to whom the engagement and authenticity it offers may be of great value. This therapeutic practice offers an approach that is of help in day-to-day life. Nonetheless, it is also true that it could be made more flexible in some respects in order to reach a wider public, maintaining the assurance of a sufficiently clear approach and bringing more people who suffer trauma and complicated grief into contact with Bioenergetic Analysis.

\section{References}

Accidents (Occupational):

Retrieved September 21, 2018 from http://www.empleo.gob.es/estadisticas/eat/eat17/ Resumen_resultados_ATR_2017.pdf

Retrieved September 21, 2018 from http://www.europapress.es/economia/laboral-00346/ noticia-mueren-618-personas-accidente-laboral-2017-18-mas-20180215141052.html.

Retrieved September 21, 2018 from https://www.lavanguardia.com/vida/20180215/ 44799619948/los-accidentes-laborales-provocaron-618-muertes-en-2017-11-mas -que-en-2016.html

Retrieved July 9, 2019 from https://www.europapress.es/economia/laboral-00346/noticia -total-652-personas-fallecieron-accidente-trabajo-2018-55-mas-hace-ano $-20190218115308 . h t m l$

American Psychiatric Association, (2014). Diagnostic and statistical manual of mental disorders: DSM-5. Manual Diagnóstico y Estadístico de los Trastornos Mentales. Madrid: Panamericana.

Berceli, D. (2012). Liberación del trauma. Santiago de Chile: Cuatro Vientos.

Klopstech, A. (2005). Revisando la catarsis y la autorregulación: consideraciones científicas y clínicas. Clin. J. IIBA, 25; 101-133. Translation by Edith Liberman.

Kübler-Ross, E., \& Kessler, D. (2006). Sobre el duelo y el dolor. Barcelona: Luciérnaga.

Levine, P. (2013). En una voz no hablada. Cómo el cuerpo libera el trauma y restaura el bienestar. Buenos Aires: Alma Lepik.

Levine, P. (2016). Sanar el trauma. Madrid: Neo Person.

Levine, P. (2018). Trauma y memoria. Barcelona: Eleftheria.

Lowen, A. (1980). Miedo a la vida. Buenos Aires: Era Naciente.

Lowen, A. (2004). Honrar el cuerpo. Malaga: Sirio.

Lowen. A. (2005). La voz del cuerpo. El papel del cuerpo en psicoterapia. Malaga: Sirio.

Lowen, A. (2013). La depresión y el cuerpo. Madrid: Alianza.

Lowen, A. (2014). La experiencia del placer. Vivencias corporales, creatividad y bioenergética para alcanzar una vida más plena. Barcelona: Paidós.

Lowen, A., \& Lowen, L. (2012). Ejercicios de Bioenergética. Barcelona: Sirio. $12^{\text {th }}$ edition. 
Magnolio. Retrieved September 21, 2018 from: http://espores.org/es/plantas/magnolia-la -flor-de-lemperador.html (Last accessed, 21 September 2018) https://es.wikipedia. org/wiki/Magnolia_grandiflora

Ogden, P., Minton, K., \& Pain, C. (2009). El trauma y el cuerpo. Un modelo sensoriomotriz de psicoterapia. Bilbao: Desclée de Brouwer.

Payás, A. (2010). Las tareas del duelo. Psicoterapia de duelo desde un modelo integrativo-relacional. Madrid: Paidós.

Pérez, J. (2006). Abordaje bioenergético del trauma. Ponencia. III Jornadas Ibéricas de Análisis Bioenergético. Bilbao 28-29 January, 2006. pp. 69-80 \& 84.

Poletti, R., \& Dobbs, B. (2004). Cómo crecer a través del duelo. Barcelona: Obelisco.

Porges, S. (2016). La Teoría Polivagal. Madrid: Pléyades.

Porges, S. (2018). Guía de bolsillo de la Teoría Polivagal. El poder transformador de sentirse seguro. Barcelona: Elefhteria.

Rothschild, B. (2015). El cuerpo recuerda. La psicofisiología del trauma y el tratamiento del trauma. Barcelona: Eleftheria.

Schroeter, V. (2016). Polivagal theory. Introduction for somatic psychotherapy. Clin. J. of IIBA., 26, 9-40.

Schroeter, V., \& Thomson, B. (2011). Dando forma. Técnicas para Analistas Bioenergéticos. San Sebastián: E. H. A. B. E. Translation: Juana Lor, Jaime Pérez y María Carmen Treku.

Van der Kolk, B. (2015). El cuerpo lleva la cuenta. Cerebro, mente y cuerpo en la superación del trauma. Barcelona: Eleftheria.

\section{About the Authors}

Vicenta Giménez Molla studied Nursing (1993) and Psychology (2001). She is a Health Psychologist, Psychotherapist in Systemic Family Therapy (2005), specialized in fertility processes. She is a member and co-founder of the Group of Interest in Psychology of the Spanish Fertility Society (2005). She is also a professor in several university master's degree related to fertility. She lives and works in San Sebastián (Spain), in private practice (2005) and in Quirónsalud Donostia Hospital (2001).

vicentagimenez@gmail.com

Amaia Alejos Martín is a licensed psychologist (2000). She has a private practice in San Sebastián, in the north of Spain. Interests include working with adults and children. Amaia worked in family service agencies before establishing her private practice, with over nineteen years' experience with children and their families.

amaia@amaiaalejospsicologa.com; https://www.amaiaalejospsicologa.com

Both graduated in Bioenergetic Analysis in January 2018. Vicenta Molla is working to complete her CBT, and Amaia Alejos Martín achieved her CBT in March 2020. Both are also members of the Association of Bioenergetic Analysis of the Basque Country (EHABE) and of the IIBA since 2013. 